\title{
Breves comentários sobre algumas obras publicadas em 2015/2016
}

SERAFIM, Milena Pavan. Agricultura familiar no Brasil: um panorama sobre as políticas e instituições. São Paulo: Annablume, 2015.

O tema da agricultura familiar ganhou relevância no debate das políticas públicas nas últimas duas décadas. Mas, o que é "agricultura familiar"? Em que ela se diferencia da agricultura empresarial? A quem beneficia a agricultura familiar? Como ela se tornou objeto de política pública? E como vem se traduzindo em termos práticos o que, em termos de discurso, até já se canta em prosa e verso? Em seu livro, Milena Pavan Serafim (professora da Faculdade de Ciências Aplicadas da UNICAMP/Limeira) oferece valiosas pistas para decifrar esses e outros enigmas. Mais ainda: em seus quatro capítulos (além da introdução e das conclusões), ela mostra quão distante, neste caso, a prática continua do discurso.

LÖWY, Michael. A política do desenvolvimento desigual e combinado: a teoria da revolução permanente. Trad. L. G Soares. São Paulo: Sunderman, 2015.

Michael Löwy é conhecido do público brasileiro, sendo, pois, dispensável sua apresentação aqui. A atenção, então, deve recair sobre este livro que veio à luz em 2010 (aqui, em 2015). Trata-se de uma reflexão em quatro atos: inicialmente, o autor se debruça sobre as concepções de revolução presentes na obra de Marx e Engels; em seguida, examina o caso mais conhecido da Rússia; na sequência, resgata a formulação mais completa da teoria da revolução permanente, de Trotsky; o último "capítulo" é dedicado a uma "conclusão". Para os interessados no tema, é um texto tão indispensável quanto "A teoria do desenvolvimento desigual e combinado", que Löwy publicara em Outubro, e, sobretudo, "The politics of combined and uneven development", publicado pela Verso já em 1981.

JINKINS, Ivana; DORIA, Kim; CLETO, Murilo (Org.). Por que gritamos golpe? Para entender o impeachment e a crise política no Brasil. São Paulo: Boitempo, 2016.

Num contexto de extrema politização, em que forças até então ocultas da extrema direita começaram a sair dos armários e, com o prestimoso auxílio dos meios de desinformação que passaram a circular ainda mais livremente suas mentiras, a "classe média" politicamente analfabeta tomou as ruas das "classes subalternas". Esta coletânea - por cujas páginas desfilam Marilena Chauí, Ruy Braga, Leda Paulani, André Singer, entre muitas/os outras/os - é uma tentativa de explicar a cadeia de fatos que desembocou na "deposição legal" da Presidenta Dilma. E, por isso, um valioso instrumento de resistência ao golpismo e aos seus executores. Nesses tempos sombrios, uma leitura indispensável. 